\title{
PRÁTICAS TESTAMENTÁRIAS EM MARIANA: OS EXECUTORES DAS ÚLTIMAS VONTADES NOS SÉCULOS XVIII E XIX
}

\author{
TESTAMENTARY PRACTICES IN MARIANA: THE EXECUTORS OF \\ THE WILLS IN THE EIGHTEENTH- AND NINETEENTH- CENTURY
}

\author{
Karina Aparecida de Lourdes Ferreira ${ }^{1}$
}

\begin{abstract}
RESUMO: O presente artigo investiga a prática testamentária na cidade de Mariana, Minas Gerais, em especial a escolha e a atuação concedida à figura do testamenteiro, ou seja, aos indivíduos responsáveis por dar cumprimento às disposições das últimas vontades. Mais especificamente, busca-se elencar os grupos envolvidos na execução do testamento, sua configuração ao longo do tempo, e as expectativas adjacentes, levandose em conta o crescimento constante da atribuição de responsabilidade ao testamenteiro. Isso será possível através da análise de 269 testamentos do Cartório do $1^{\circ}$ Ofício de Mariana registrados entre os anos de 1748 e 1848 . O trabalho pretende apontar como a presença de sociabilidades mais sólidas carregavam formas mais eficazes de lembrança, colocando em questão a própria função salvífica do testamento.
\end{abstract}

PALAVRAS-CHAVE: testamentos; testamenteiros; família; memória; Mariana.

ABSTRACT: This article investigates the testamentary practice in the city of Mariana, Minas Gerais, especially the choice and performance given to the executor figure, that is, to the individuals in charge of fulfilling the last wills. More specifically, it researchs the groups involved in testament execution, their configuration over time, and the surrounding expectations, taking into account the constant growth of the responsibility attributed to the executor. This will be possible through the analysis of 269 testaments of Mariana's 1st Office Registry recorded between the years 1748 and 1848. The paper aims to point out how the presence of a stronger sociability meant more effective forms of remembering, calling into question the saving function of the will.

KEYWORDS: wills; executors; family; memory; Mariana.

\footnotetext{
* O presente artigo é parte reformulada da dissertação de mestrado intitulada Morte, memória e família: a prática e os atores testamentários em Mariana, 1748-1848. A pesquisa foi desenvolvida junto ao Programa de Pós-Graduação em História da Universidade Federal de Minas Gerais, com apoio financeiro do Conselho Nacional de Desenvolvimento Científico e Tecnológico (CNPq).

1 Mestra em História pela Universidade Federal de Minas Gerais. Contato: karina.ferreira.alf@gmail.com
} 


\section{A redação do documento de última vontade}

Na cidade de Mariana, assim como em todo o Ocidente católico entre os séculos XV e XIX, dois ritos costumeiramente antecediam a morte de uma pessoa: o segundo, de acordo com a ordem dos eventos, era essencialmente religioso, consistia na administração por um sacerdote dos últimos sacramentos ao moribundo; o primeiro possuía feição mais complexa, nem puramente sagrado nem completamente secular, tratava-se da confecção do testamento, ato tabelionesco acionado e levado à cabo pelo próprio indivíduo que se precavia para quando do fato de sua morte. A prática de redigir documentos de últimas vontades, que acompanha as sociedades ocidentais há séculos, desempenha a função de preparar o testador para sua morte ao registrar suas resoluções sobre fortuna e crenças religiosas.

Até a segunda metade do século XIX, para o Brasil, o testamento compreendia essa referida dupla finalidade: jurídica e religiosa (RODRIGUES, 2005). Funcionava, por conseguinte, como instrumento para as disposições patrimoniais, de sucessão e herança, assim como veículo para a salvação da alma. Em função disso, o documento recebeu orientações do Estado submetendo-se às leis portuguesas reformuladas pelas Ordenações Filipinas (ALMEIDA, 1870) - e da Igreja - sob regulamentação das Constituições Primeiras do Arcebispado da Bahia de 1707, a maior compilação legislativa católica brasileira. ${ }^{3}$ Além de tais determinações, a circulação de escritos didáticos conhecidos como "manuais de bem morrer" e opúsculos que instruíam a escrita do testamento (CASTRO, 1627: 100-106; ANTUNES, 2005), fornecendo inclusive uma estrutura a ser somente preenchida com os dados pessoais do testador, fizeram com que o registro assumisse um aspecto de rigidez, convencionando-se um modelo padronizado de redação. Por outro lado, cumpre assinalar que a fonte contém expressões e espaços singulares em conteúdo, considerando que se tratava de um ato personalíssimo onde a liberdade de testar deveria estar assegurada (ALMEIDA, 1870: 917-919; DA

\footnotetext{
${ }^{3}$ No livro IV das Constituições são dedicados mais de vinte títulos orientando não somente a redação do testamento, mas as condições dos sepultamentos e os ritos fúnebres como um todo (DA VIDE, 1853).
} 
VIDE, 1853: 279). Assim, mesmo havendo recomendações para sua produção e validação, esse documento também deve ser enxergado como um relato individual por meio do qual o testador expunha suas derradeiras vontades, ${ }^{4}$ ainda que marcadas pelas conjunturas de seu tempo. Para os historiadores de hoje, o testamento se afigura como testemunho de práticas sociais e universos culturais que têm muito a dizer sobre os recortes temporais e espaciais aos quais se referem.

Existem algumas partes mais ou menos definidas e passíveis de identificação nos testamentos: a apresentação (profissão de fé, local e data, pedidos de intercessão da comunidade celeste, etc.); a identificação do testador (nome, naturalidade, filiação, estado conjugal, etc.); os legados espirituais (local de sepultamento, vestes mortuárias, pedidos de missas, etc.); as disposições econômicas (nomeação dos herdeiros, acerto de dívidas, destinação da terça, etc.). Por fim, para efeito de autenticação, nomeava-se os testamenteiros, concedia-se lhes plenos poderes, estipulando o tempo para que as determinações fossem cumpridas, indicava-se as testemunhas, o local e a data. A estrutura do ato era organizada de forma a criar um discurso homogêneo e internamente articulado. Desse modo, mesmo sendo possível identificar espaços direcionados ao religioso ou ao econômico, por exemplo, considerações de naturezas diferentes por vezes se entrecruzavam e perpassavam outras áreas do discurso.

Um dos elementos que emergem da leitura desses relatos, e que interessa particularmente para os propósitos desse artigo, é a evocação de agentes que, pela morte do testador, deveriam assumir certas responsabilidades. Aquele que recorria ao registro de última vontade acionava um conjunto de grupos que tornava o acontecimento de sua morte uma experiência não mais solitária, algo que, por sinal, deveria ser evitado com vistas a uma boa morte.

\footnotetext{
4 "Do século XIII ao século XVIII, o testamento foi o meio para cada indivíduo exprimir, frequentemente de modo muito pessoal, seus pensamentos profundos, sua fé religiosa, seu apego às coisas, aos seres que amava, a Deus, bem como as decisões que havia tomado para assegurar a salvação de sua alma e o repouso de seu corpo. O testamento era, então, mais que um simples ato de direito privado para a transmissão de uma herança, um meio para cada um afirmar seus pensamentos profundos e suas convicções." (ARIÈS, 2012: 71).
} 
Nesse sentido, foi temendo da morte e querendo salvar sua alma pela misericórdia de Deus que, em 1824, Ana Joaquina Soares formalizou suas últimas vontades. A testadora nomeou como herdeira uma filha natural nascida antes de seu casamento com o furriel Francisco Esteves de Magalhães, dispôs sobre os detalhes de seu funeral e deixou uma escrava coartada. A respeito do montante de sua terça, Ana Joaquina afirmou que "tudo aquilo que restar da minha Terça sera impregado no que deixo recomendado ao referido meu marido, e este saptisfara com hum juramento". 5 Além dos cuidados com o corpo e com a alma que sucediam o óbito, algumas medidas para uma passagem bem-sucedida para o além envolviam, como se vê no relato de Ana Joaquina, uma adequada preparação para a morte, da qual, afinal, poderiam depender os procedimentos post-mortem. Está claro que a confecção do testamento ou a orientação a pessoas de confiança - no caso citado, o marido da testadora sobre como administrar bens e memória do morto compunham uma primeira etapa do jogo da salvação. Como já demonstrado por João José Reis, antes de mais nada, uma boa morte passava pela elaboração de um plano, "significava que o fim não chegaria de surpresa para o indivíduo, sem que ele prestasse contas aos que ficavam e também os instruísse sobre como dispor de seu cadáver, de sua alma e de seus bens terrenos" (REIS, 1991: 92).

A preocupação pela morte imprevista era contornada, como se vê, pela transmissão a outras pessoas de anseios e pendências, dotando de capacidade de ação esses sujeitos intermediários, convertidos, então, em representantes do morto. Ultrapassando a fronteira do individual, a agremiação em irmandades ou ordens terceiras atuava, de forma semelhante, como mecanismo para assegurar benefícios temporais e espirituais aos irmãos, visto que o associativismo leigo primava pela prestação de serviços funerários e ações caritativas (SCARANO, 1978: 79; BOSCHI, 1986: 150; NASCIMENTO, 2006: 169).

A necessidade de controle sobre a post-mortem, contudo, era mobilizadora de atitudes antecipatórias por parte de alguns indivíduos, como foi

\footnotetext{
${ }^{5}$ Arquivo Histórico da Casa Setecentista de Mariana. Ano 1825, Códice 40, auto 919, $1^{\circ}$ ofício. Laboratório Multimídia de Pesquisa Histórica. Inventário com testamento de Ana Joaquina Soares [1824].
} 
o caso do Doutor Manoel Brás Ferreira. O português redigiu seu testamento em 1786 no qual se declarou irmão da Ordem Terceira de São Francisco de Mariana, casado com Antônia Luiza da Silva Leal, sua testamenteira, com quem teve dois filhos. Sobre as missas por sua alma, afirmou:

Declaro que por ter mandado ja fazer em Portugal cendo ainda solteiro os sufrajos da minha alma e outras esmollas e legados Piyos ainda a beneficio de meus Parentes de que conservo os documentos com as certidoens de sinco mil missas ou pouco menos relativas ao mesmo sofrajo nada mais desponho a este respeito nem disto mesmo sera obrigada a minha testamenteira a dar contas em Juizo ficando lhe [?] livre a puder dar as esmollas que bem lhe paresser aos pobres mendicantes no dia do meu funeral. ${ }^{6}$

Previdências como as de Manoel Ferreira, que quase metamorfoseavam um documento de últimas vontades em registro de prestação de contas de cuidados já cumpridos, não eram comumente registradas pela população testamentária. A medida, em sua singularidade, é profundamente reveladora, não somente da eficácia atribuída aos sufrágios e obras pias, mas da necessidade de preparação para a morte, como observou Roger Chartier:

Toda uma gama de gestos deve também preparar para a morte. Os sufrágios, missas, orações, esmolas e jejuns, exigidos pelo testamento, são igualmente, e talvez acima de tudo, práticas da vida cristã no pensamento da morte. O Manière de faire testament salutaire marca bem ao mesmo tempo a reconhecida eficácia das missas e orações reivindicadas pelo falecido e a necessidade de fazer um exercício de preparação para a morte [...] (CHARTIER, 1976: 67. Tradução nossa). ${ }^{7}$

A recordação da morte, "com a qual nos reprimimos, e abstemos dos pecados" (DA VIDE, 1853: 291), tornava-se importante instrumento para a fixação de preceitos cristãos, sustentando a necessidade de se precaver para uma morte socialmente desejada. Tal memória é evocada como reveladora do

\footnotetext{
${ }^{6}$ AHCSM. Ano 1787, Códice 114, auto 2368, $1^{\text {o }}$ ofício. LAMPEH. Inventário com testamento de Manoel Brás Ferreira [1786].

7 "Toute une gamme de gestes doit aussi préparer la mort. Les suffrages, messes, oraisons, aumônes et jeûnes, que l'on demande par testament, sont également, et peut-être surtout, pratiques de la vie chrétienne dans la pensée de la mort. La Manière de faire testament salutaire marque bien à la fois l'efficace reconnu aux messes et oraisons réclamées par le défunt et la nécessité d'en faire un exercice de la préparation à la mort [...]"
} 
dado irremediável da breve trajetória humana. A consciência da própria morte é aquilo que mobilizava as sensibilidades em direção da busca de imortalidade, numa contradição que sustentava em sua zona intermediária um complexo quadro de emoções e rituais fúnebres (MORIN, 1997).

$\mathrm{O}$ exercício das últimas vontades, ao ser aplicado à tecelagem do bem morrer, pode-se dizer, se constituiu a partir da delegação de funções, da atribuição de condutas através de pedidos, recomendações ou apelos. Por meio da distribuição dos cuidados a outrem, o indivíduo se cercava por vínculos de solidariedade, reiterando na morte sua qualidade de evento social. Tal proceder exigia a construção e perpetuação, mais ou menos duradoura, da lembrança do morto. Em outras palavras, o ato notarial surgia de um esforço de seu autor em orquestrar meios de recordação que se prestassem a manifestações de solidariedade ao mobilizar certos grupos sociais, servindo de apoio para a perpetuação de certas ações e de uma dada imagem do testador na memória coletiva. Resoluções pessoais eram expressadas ao mesmo tempo em que realçava vínculos sociais e familiares, fundava procedimentos ritualísticos, e instruía os que ficaram vivos sobre como proceder com o que era de sua alçada após sua morte. Desempenhava também a função de reforço identitário e da coesão grupal, para o que importava, diga-se de passagem, menos os significados da linguagem apregoada pelos ritos e mais a participação dos grupos envolvidos na ocasião (ARAÚJO, 1997: 225). Assim, mais do que um ato jurídico - aquilo que hoje representa o testamento - esse cuidado ante mortem ao assumir o viés de ferramenta de precaução para uma boa morte tornava-se um instrumento funerário destinado a auxiliar, em seu domínio, a lembrança do testador. Esse recurso, ao supor a presença da ausência, parafraseando François Dosse, permaneceu como elo fundamental entre o mundo dos vivos e dos mortos (DOSSE, 2004: 183-184).

A escolha dos executores testamentários 
Ao longo do século XVIII e, mais intensamente, do XIX, os testamentos marianenses registraram um lento, mas progressivo encolhimento, em particular das cláusulas de natureza religiosa, acompanhado da crescente delegação, parcial ou total, dos cuidados funerários ao testamenteiro (FERREIRA, 2019). Essas duas mudanças - simplificação e atribuição ao executor - em sua ocorrência pari passu não pareceram mera casualidade. Somando-se a isso, a historiografia que fez uso dos testamentos, tanto para o estudo das atitudes diante da morte como para o de outros fenômenos das sociedades, foi consensual em identificar o testamenteiro como sendo alguém, no mais das vezes, recrutado no interior da família (ARAÚJO, 1997: 119; FARIA, 1998: 274; SCOTT, 1999: 337). A análise do espaço específico destinado à escolha do executor testamentário corresponde ao objetivo de verificar o impacto do enraizamento e do envolvimento da família na concepção das últimas vontades.

Considerando o testamento em sua totalidade, ou seja, no conjunto de suas cláusulas, verificou-se o aumento progressivo dos testadores que deixaram algum aspecto do cerimonial mortuário ou da disposição dos bens ao arbítrio do executor da vontade. Analisando de uma só vez o conjunto da documentação distribuída no decorrer de uma centúria, verifica-se que essa prática foi corrente em cerca de um terço dos testadores. Dividindo os dados em recortes temporais menores - em quatro grupos que abrangem, cada um, um período de vinte e cinco anos - observa-se que nos anos finais a atribuição ao testamenteiro já estava presente em mais da metade dos testamentos.

Tabela 1 - Atribuição de poder de decisão ao testamenteiro em quatro períodos, cidade de Mariana

\begin{tabular}{c|cccccccccc}
$\begin{array}{c}\text { Delegação } \\
\text { ao } \\
\text { testamenteiro }\end{array}$ & $1748-1773$ & $1774-1798$ & $1799-1823$ & $1824-1848$ & \multicolumn{2}{c}{ Total } \\
\hline & $\mathrm{N}$ & $\%$ & $\mathrm{~N}$ & $\%$ & $\mathrm{~N}$ & $\%$ & $\mathrm{~N}$ & $\%$ & $\mathrm{~N}$ & $\%$ \\
Não & 57 & 87,69 & 53 & 72,60 & 35 & 51,47 & 26 & 41,27 & 171 & 63,57 \\
Sim & 8 & 12,31 & 20 & 27,40 & 33 & 48,53 & 37 & 58,73 & 98 & 36,43
\end{tabular}


Fonte: LAMPEH, AHCSM. $1^{\circ}$ Ofício, inventários post-mortem. AHCSM, $1^{\circ}$ Ofício, livros de registro de testamento. FamilySearch, livros de assentamentos de óbitos da Paróquia de Nossa Senhora da Assunção, Catedral de Mariana. ${ }^{8}$

A centralidade possuída pelo testamenteiro para a realização das disposições firmadas para depois da morte foi apontada por Milton Stanczyk Filho. $\mathrm{O}$ autor argumentou que toda a concepção e o funcionamento do testamento e das cláusulas e recomendações nele aferidas estavam assentadas sobre um "sistema de garantias" que era acionado com vistas à execução plena das vontades do testador. Excetuando-se as questões que diziam respeito à caução da validade do documento em conformidade com a legislação vigente, o testamenteiro era o sujeito principal que detinha o controle sobre as decisões de um modo geral, logo, personificava a garantia de sua execução. A indicação do nome para a função não era, pois, deliberação qualquer. Pelo contrário, envolvia a reflexão sobre as possibilidades disponíveis nas redes de relacionamentos do testador, tendo em vista a inspiração de confiança e capacidade, já que se esperava minimamente que suas determinações fossem cumpridas (STANCZYK FILHO, 2005: 52-62).

$\mathrm{O}$ executor testamentário, em outros termos, era a pessoa diretamente incumbida pelo testador para assegurar que seus atos jurídicos decididos em vida continuassem a ter efeito após sua morte. Os testamenteiros eram correntemente nomeados nos documentos "procuradores, administradores e benfeitores", e autorizados a realizar todas as transações financeiras necessárias para o cumprimento da vontade do morto - o que envolvia cobranças, pagamentos, vendas, partilhas, etc. -, "sem nenhuma contenda de justiça".

\footnotetext{
${ }^{8}$ Para os objetivos desse trabalho, a amostra documental foi composta exclusivamente por testamentos, selecionados predominantemente entre os documentos do Arquivo da Casa Setecentista de Mariana. Nesse sentido, parte dessa documentação foi localizada entre os inventários mantidos pelo LAMPEH, consultados em sua totalidade, enquanto outro conjunto, colhido no intervalo de dez em dez anos, está localizado nos livros de registros de testamentos conservados na Casa. Por fim, foram incluídos alguns poucos registros que surgiram transcritos entre os assentos de óbitos da Catedral de Mariana, estes selecionados no intervalo de vinte em vinte anos, com o fim de elucidar outras questões que não serão abordadas nesse artigo. Tomouse os devidos cuidados para evitar possíveis duplicações advindas da eventual presença de um mesmo testamento registrado em mais de um conjunto documental.
} 
Esperava-se da pessoa designada para a função a representação formal do indivíduo solicitante do compromisso uma vez impedido de ação jurídica por ocasião de seu falecimento. O executor deveria, pois, efetuar as disposições registradas em testamento, onde poderia estar antevisto até o mais ínfimo procedimento, ou ter as medidas parcial ou totalmente submetidas ao arbítrio do testamenteiro. Enquanto representante legal de indivíduos pessoalmente incapacitados de fazer valer as próprias vontades devido à extinção de sua presença física da esfera mundana, o testamenteiro, logo, deveria ser pessoa de confiança, apto, e devidamente orientado para o exercício da manutenção da personalidade jurídica do morto. ${ }^{9}$

Ao contrário do que ocorria no direito romano, a lei luso-brasileira não exigia que o executor da vontade fosse escolhido entre os herdeiros forçados, embora isso acontecesse com frequência. Tratava-se, antes de mais nada, de uma indicação cuidadosa (LEWIN, 2003: 23-24). Ultrapassando uma simples formalidade, a seleção do testamenteiro obedecia a uma estratégia de confiança, recaindo sobre o executor uma imagem de honorabilidade e boa reputação (ARAÚJO, 1997: 118-119). É compreensível, portanto, que as indicações dos atores envolvidos na administração da vontade se concentrassem entre pessoas próximas do testador ou de reconhecido prestígio na comunidade.

Procurou-se investigar esses graus de proximidade entre testador e testamenteiro a fim de traçar uma tendência da escolha dos executores e os critérios envolvidos nessa atividade. Criou-se quatro categorias gerais, tendo como parâmetro vínculos pessoais ou qualidades associadas aos nomes apontados pelos testadores. Os executores foram classificados segundo as categorias cônjuge, parentes, pessoas reconhecidas socialmente - reunindo nomes precedidos por títulos, patentes ou cargos de confiança -, e os nomes desacompanhados de qualquer informação adicional foram enquadrados em sem vínculo declarado. Por fim, em outros foram agrupados alguns casos

\footnotetext{
${ }^{9}$ Otto Gerhard Oexle explicou que para as concepções anteriores ao direito moderno os mortos permaneciam sendo pessoas no sentido jurídico, ou seja, detentores de direitos e deveres na sociedade dos vivos, logo, naquele contexto ainda é adequado se falar em personalidade jurídica de mortos (OEXLE, 1996: 29).
} 
isolados que fugiram ao padrão, como a nomeação das Ordens Terceiras que, a partir de finais da década de 1760, pelas leis pombalinas, estavam proibidas de desempenhar a função.

Tabela 2 - Relação entre testador e testamenteiro em quatro períodos, cidade de Mariana

\begin{tabular}{|c|c|c|c|c|c|c|c|c|c|c|}
\hline & \multicolumn{2}{|c|}{$1748-1773$} & \multicolumn{2}{|c|}{$1774-1798$} & \multicolumn{2}{|c|}{$1799-1823$} & \multicolumn{2}{|c|}{$1824-1848$} & \multicolumn{2}{|c|}{ Total } \\
\hline & $\mathrm{N}$ & $\%$ & $\mathrm{~N}$ & $\%$ & $\mathrm{~N}$ & $\%$ & $\mathrm{~N}$ & $\%$ & $\mathrm{~N}$ & $\%$ \\
\hline $\begin{array}{l}\text { Pessoas reconhecidas } \\
\text { socialmente }\end{array}$ & 13 & 20,00 & 22 & 30,14 & 23 & 33,82 & 20 & 31,75 & 78 & 29,00 \\
\hline Parentes & 7 & 10,77 & 19 & 26,03 & 20 & 29,42 & 24 & 38,10 & 70 & 26,02 \\
\hline Sem vínculo declarado & 30 & 46,15 & 17 & 23,29 & 5 & 7,35 & 9 & 14,28 & 61 & 22,67 \\
\hline Cônjuge & 12 & 18,46 & 11 & 15,07 & 19 & 27,94 & 9 & 14,28 & 51 & 18,96 \\
\hline Outros $^{10}$ & 3 & 4,62 & 4 & 5,47 & 1 & 1,47 & 1 & 1,59 & 9 & 3,35 \\
\hline Total & 65 & 100 & 73 & 100 & 68 & 100 & 63 & 100 & 269 & 100 \\
\hline
\end{tabular}

Fonte: LAMPEH, AHCSM. $1^{\circ}$ Ofício, inventários post-mortem. AHCSM, $1^{\circ}$ Ofício, livros de registro de testamento. FamilySearch, livros de assentamentos de óbitos da Paróquia de Nossa Senhora da Assunção, Catedral de Mariana.

De maneira geral, as solicitações permaneceram bem distribuídas entre as quatro categorias consideradas isoladamente. A reunião, contudo, entre as nomeações de parentes e cônjuges apontou para a preferência por pessoas ligadas ao testador através de relações familiares. Tal constatação apenas endossa a bibliografia que trabalhou com testamentos e apontou como a testamentaria era um encargo sobretudo familiar (ARAÚJO, 1997: 119; FARIA, 1998: 274; SCOTT, 1999: 337). Foi também comum a indicação de pessoas que usufruíam de certo reconhecimento social, como portadores de títulos, patentes militares e membros do corpo eclesiástico. Em quase um quarto dos registros não foi possível estabelecer qual foi o critério empregado na escolha do executor, o que não significa a sugestão de uma ausência de estratégia deliberadamente tomada pelo testador, mas apenas que tal estratégia não foi tornada explícita. Além disso, recorde-se que como a família figurava

\footnotetext{
${ }^{10}$ Incluídos nomeação de agremiações leigas (3), amigo (1), patrício (1), sócia em imóveis (1), antigo vínculo de coabitação (1), filho de uma crioula criado pelo testador (1), e um testamento em que essa informação esteve ilegível.
} 
como nó cego nos testamentos, nem sempre as relações entre personagens presentes nos registros foram dadas a ver. Assim, não se pode excluir a hipótese de que parte dos executores enquadrados nas categorias que reuniam pessoas qualificadas por títulos ou cujos nomes não foram precedidos por nenhum indicador tivessem alguma relação familiar com o testador. A identificação desses vínculos invisíveis demandaria um exercício de reconstituição familiar, esforço que fugiria, infelizmente, do escopo desse trabalho (LIBBY; FRANK, 2015).

Para além da identificação de preferências, o movimento dessas categorias ao longo do tempo merece uma análise mais acurada. A começar pelo recrutamento no interior do que se escolheu chamar por pessoas reconhecidas socialmente, foi registrada uma constante de nomeações que pairou próxima aos 30\% sem apresentar qualquer sinal de decréscimo até os anos finais. Foram incluídos nesse grupo testamenteiros cujos nomes estiveram associados a títulos indicadores de prestígio naquela sociedade, mormente padres, alferes, capitães, cônegos, tenentes, dentre outros ligados a cargos militares ou magistrados. No que cabe à indicação de indivíduos portadores de patentes militares, fazer parte dos corpos de ordenanças ou milícias implicava em inserção nas malhas do poder local e promoção social. A aquisição de títulos dessa natureza, muito requisitados pelos "homens bons" da terra, lhes concedia, em troca do serviço prestado, privilégios materiais e simbólicos que confluíam para a consolidação de distinção social (MENDES, 2010: 23-26; COSTA, 2006: 41; SILVA, 2005). Os membros do quadro eclesiástico, de modo semelhante, respaldados pela importância conferida ao culto religioso e pela capacidade de mobilização simbólica da dignidade, assumiram função de normalização e mediação social (ARAÚJO, 1997: 87). Ao mesmo tempo em que inspiravam reconhecimento social, eram figuras de autoridade religiosa e intermediários privilegiados entre Deus e os fiéis (BRÜGGER, 2013: 286), dos quais se esperava o cuidado para que as providências post-mortem se dirigissem para o bem da alma dos paroquianos. 
Ao contrário da imutabilidade verificada na categoria que concentrava setores sociais providos de status, as demais categorias passaram por mudanças consideráveis. A indicação de pessoas sem a explicitação dos critérios envolvidos nessa escolha, que no primeiro quarto da amostra abocanhava $46,15 \%$, cedeu paulatinamente espaço para a emergência da família. A linha reservada aos parentes, incluindo-se nela os vínculos de parentesco espiritual, como se vê, apresentou crescimento constante, embora em seu interior os diferentes graus de proximidade entre testamenteiro e testador tenham se mantido estáveis. O recrutamento no âmbito da parentela era encabeçado pelos filhos (28 casos) seguidos pelos irmãos (19), compondo juntos 67,14\% da categoria. Em menor monta, apareceram, em ordem de preferência, nomeações de sobrinhos, primos, afilhados, compadres, genros, e parente sem mais especificações. Tomando como critério o país de origem dos testadores (apresentado na tabela a seguir), é visível que entre nascidos no Brasil a disposição das preferências não correspondeu à configuração geral da tabela anterior.

Tabela 3 - Relação entre testador e testamenteiro conforme país de origem, cidade de Mariana

\begin{tabular}{|c|c|c|c|c|c|c|c|c|c|c|}
\hline & \multicolumn{2}{|c|}{ Portugal } & \multicolumn{2}{|c|}{ Brasil } & \multicolumn{2}{|c|}{ África } & \multicolumn{2}{|c|}{$N I$} & \multicolumn{2}{|c|}{ Total } \\
\hline & $\mathrm{N}$ & $\%$ & $\mathrm{~N}$ & $\%$ & $\mathrm{~N}$ & $\%$ & $\mathrm{~N}$ & $\%$ & $\mathrm{~N}$ & $\%$ \\
\hline $\begin{array}{l}\text { Reconhecidos } \\
\text { socialmente }\end{array}$ & 42 & 33,60 & 28 & 24,77 & 7 & 33,33 & 1 & 10,00 & 78 & 29,00 \\
\hline Parentes & 23 & 18,40 & 41 & 36,28 & 3 & 14,28 & 3 & 30,00 & 70 & 26,03 \\
\hline Sem vínculo declarado & 42 & 33,60 & 12 & 10,61 & 6 & 28,58 & 1 & 10,00 & 61 & 22,67 \\
\hline Cônjuges & 12 & 9,60 & 29 & 25,66 & 5 & 23,81 & 5 & 50,00 & 51 & 18,96 \\
\hline Outros & 6 & 4,80 & 3 & 2,65 & - & - & - & - & 9 & 3,34 \\
\hline Total & 125 & 100 & 113 & 100 & 21 & 100 & 10 & 100 & 269 & 100 \\
\hline
\end{tabular}

Fonte: LAMPEH, AHCSM. $1^{\circ}$ Ofício, inventários post-mortem. AHCSM, $1^{\circ}$ Ofício, livros de registro de testamento. FamilySearch, livros de assentamentos de óbitos da Paróquia de Nossa Senhora da Assunção, Catedral de Mariana.

Os dados apresentados demonstram que os nascidos no Brasil estiveram muito menos afeitos à indicação de executores desligados do universo da família. Conquanto a requisição de pessoas com status fosse disseminada em 
patamares não muito distantes entre todos os grupos, entre nascidos no Brasil essa prática ficou atrás da nomeação de parentes e cônjuges. O peso do movimento histórico-demográfico que marcou o desenvolvimento de Mariana e região se fez sentir na indicação dos testamenteiros por parte dos indivíduos que foram submetidos ao impacto inicial do desenraizamento, voluntário ou forçado. A bibliografia sobre o tema já apontou a existência e o funcionamento de redes de acolhimento e sociabilidade, as quais poderiam ou não se configurar em torno de laços familiares, que recepcionavam a população migrante em Mariana e impulsionavam sua inserção nas teias sociais locais (LEMOS, 2012: 74-81; LOPES, 2012). No entanto, no que cabe à eleição dos executores da vontade dos testadores, a maior parte das relações que escapavam dos círculos familiares foram suprimidas do registro, impedindo a compreensão do papel das redes profissionais, por exemplo, no momento do falecimento de um de seus integrantes. Desse modo, a dificuldade na identificação da massa de "anônimos" mobilizada nas fontes compromete a interpretação das estratégias de confiança adotadas, sobretudo pelos que não eram nascidos na região. Por outro lado, fica demonstrado como, num contexto de maior enraizamento, recorrer a familiares era a opção que inspirava maior segurança para a tarefa do cumprimento das últimas vontades.

Partindo para a categoria seguinte, considerando a amostra total, a prática de eleger o cônjuge como executor compôs 18,96\% dos casos, o que corresponde a 78,46\% dos indivíduos casados. ${ }^{11}$ É evidente que a categoria reservada aos cônjuges oscila conforme a presença de testadores casados, por isso fez-se necessário gerar uma tabela auxiliar que isolasse essa pequena população. Tendo em vista o tamanho da amostra, muito menor numericamente, e a distribuição dos casos ao longo do tempo, optou-se por agrupar em apenas dois períodos os dados apresentados na tabela a seguir:

\footnotetext{
${ }^{11}$ Para Campos de Goitacazes dos séculos XVII e XVIII, Sheila Faria encontra um percentual de $76 \%$, o que, segundo sua interpretação, era indicativo de uma vida em comum sem grandes conflitos (FARIA, 1998: 274-275).
} 
Tabela 4 - Relação entre testadores casados e testamenteiros em dois períodos, cidade de Mariana

\begin{tabular}{l|cccccc}
\multicolumn{1}{c}{} & \multicolumn{2}{c}{$1748-1799$} & \multicolumn{2}{c}{$1800-1848$} & \multicolumn{2}{c}{ Total } \\
\hline \multirow{3}{*}{ Cônjuges } & $\mathrm{N}$ & $\%$ & $\mathrm{~N}$ & $\%$ & $\mathrm{~N}$ & $\%$ \\
Parentes & 23 & 67,65 & 28 & 90,32 & 51 & 78,47 \\
Pessoas reconhecidas socialmente & 4 & 11,76 & 2 & 6,45 & 5 & 9,23 \\
Sem vínculo declarado & 3 & 8,83 & 1 & 3,23 & 4 & 6,15 \\
Total & 4 & 11,76 & - & - & 4 & 6,15 \\
& 34 & 100 & 31 & 100 & 65 & 100
\end{tabular}

Fonte: LAMPEH, AHCSM. $1^{\circ}$ Ofício, inventários post-mortem. AHCSM, $1^{\circ}$ Ofício, livros de registro de testamento. FamilySearch, livros de assentamentos de óbitos da Paróquia de Nossa Senhora da Assunção, Catedral de Mariana.

A leitura das preferências das pessoas casadas ao longo do tempo mostrou ter sido o cônjuge, em qualquer período, a opção mais buscada. Mas, para além disso, observou-se um aumento da indicação dos consortes para a ocupação com a testamentaria: de 67,65\% na segunda metade do Setecentos para $90,32 \%$ na primeira metade do Oitocentos. ${ }^{12}$ Essa diferença torna-se mais discreta quando levados em conta os reinóis que já haviam contraído matrimônio antes de migrarem para as Minas (apenas 4,68\% declararam ter deixado mulher em Portugal, todos no século XVIII). Foi esse o caso de José Alves da Boa Vista, nascido na cidade do Porto, deixou esposa para se lançar à aventura mineradora, ou às atividades a ela relacionadas. Sem filhos, em testamento de 1778 nomeou seu irmão João Alves, morador em Camargos, testamenteiro e herdeiro de sua parte dos bens do casal, declarando que "no

\footnotetext{
${ }^{12} \mathrm{O}$ peso desses percentuais deve ser ponderado, uma vez que a população casada que legou testamentos no período correspondeu a um pequeno recorte no total da documentação coletada. Desse modo, como é mostrado na tabela, pequenas variações numéricas corresponderam a consideráveis mudanças percentuais. Apesar dessa deficiência de amostragem e das possíveis distorç̃os advindas, optou-se por manter essa relação de dados, visto que em estudo anterior, abrangendo as freguesias do Termo de Mariana, e com um maior número de testadores casados, também foi identificado o aumento (de 59,37\% para 87,80\%) da indicação dos cônjuges para a ocupação com a testamentaria (FERREIRA, 2016: 52). Assim, apesar da ciência da fragilidade desses dados, considerou-se importante apresá-los, com as ressalvas cabíveis, porque eles sinalizam para um fenômeno mais amplo de fortalecimento das relações familiares que merece investigações mais detalhadas em trabalhos futuros.
} 
cazal meu e de minha mulher em Portugal não há bens alguns e a mesma vive pobremente valendose das assistencias que lhe faço como posso". ${ }^{13} \mathrm{O}$ condutor demográfico e o peso do desenraizamento tiveram impacto nessa e em outras disposições dos testadores, como se tem tentado demonstrar, mas o problema não se encerra nele. A esse respeito, a leitura do movimento da escolha do executor feita para Lisboa por Ana Cristina Araújo parece bastante pertinente. A autora observou que entre 1700 e 1830 o recrutamento de pessoas não inseridas no espaço da família caiu progressivamente, ao passo que se registrou o movimento contrário na posição dos cônjuges. Esse deslocamento da atribuição com o fortalecimento da responsabilidade conjugal foi interpretado como um dos sinais da emergência de um novo relacionamento entre família, do qual faz parte o alargamento da reciprocidade conjugal. "Este avanço traduz o lado oculto de uma realidade que, de diversos ângulos, se impõe aos nossos olhos, ou seja, a emergência, sem reservas, da família como núcleo afectivo, com maior margem de autonomia e liberdade de ação" (ARAÚJO, 1997: 119). Aqui, a raridade de testemunhos da época que tratassem dos sentimentos que uniam os casais torna tarefa difícil a de tecer considerações muito profundas sobre o afeto no interior do casamento, mas os testamentos seguem oferecendo importantes indícios, seja através da serialização ou pelas manifestações pessoais, ainda que contidas, de afeição e confiança. ${ }^{14}$

Se os dados relativos ao vínculo entre testador e testamenteiro designado ao longo do tempo puderem ser solidificados e extrapolados para outros fenômenos da vida cotidiana estar-se-ia então diante de um processo de mudança da família marianense, no qual um dos traços centrais seria a afirmação da família conjugal. Mas, embora sinalizações nesse sentido sejam

\footnotetext{
${ }^{13}$ AHCSM. Ano 1778, Livro de Registro de Testamento n ${ }^{\circ} 54,1^{\circ}$ ofício. Testamento de José Alves da Boa Vista [1778].

${ }^{14}$ Citando um testamento do século XVIII do duque de Sain-Simon, Philippe Ariès destacou a originalidade do registro: "Tais testemunhos são raros: é como se os homens não gostassem de falar do sentimento que ligava os esposos, a não ser nos testamentos, onde se tornam mais frequentes. É difícil para o historiador interpretar o silêncio que reina sobre vastos domínios da vida: ora ele significa a indiferença ou a ignorância, ora o pudor e o segredo. Existiam coisas que não se diziam: o amor conjugal era uma delas. Às vezes esse silencio é rompido, e isso quase sempre ocorre às vésperas da morte.” (ARIÈS, 1985: 158-159).
} 
apontadas por outros autores (BOTELHO, 2013: 280-281), pesquisas melhor embasadas ainda estão por serem feitas.

Os dados elencados oferecem alguns indícios sobre as mudanças que atingiram as demais cláusulas testamentárias. Observou-se que a estratégia de segurança ligada à honorabilidade e boa reputação do executor permaneceu atuante. A procura por pessoas portadoras de títulos e patentes que inspiravam prestígio não registrou variação, sinal da permanência do capital simbólico adquirido ao envergar títulos promotores de distinção social. Do mesmo modo, dentro das relações de parentesco, os diferentes graus de proximidade entre testador e testamenteiro não se alteraram, sendo preferidos sempre filhos (as) e irmãos (as), ou seja, os parentes de primeiro grau em linha reta ou colaterais de segundo grau. Não obstante essa relativa estabilidade, observou-se o crescimento da ingerência da família, tanto da parte dos parentes de um modo geral, como dos cônjuges, em detrimento das pessoas sem relação evidente. As informações encontradas apontaram para um processo em curso no século XIX de maior encaminhamento das decisões do post-mortem para os quadros familiares. A indicação do executor sofreu o peso do enraizamento, os nascidos em Mariana preferiram parentes e cônjuges a qualquer outro grupo. Associado a esse fator, parece haver uma crescente atribuição de confiança a indivíduos ligados por laços familiares.

Não se pretende sugerir que o afeto direcionado ao ambiente familiar tenha sido inventado naquele período, e muito menos que a família tivesse, até então, ocupado papel marginal naquela sociedade. A família assumiu centralidade no decorrer do período colonial, desempenhando função de principal gestora das relações políticas e econômicas, se configurando como base da organização social. ${ }^{15}$ Recorde-se que no ato de testar eram feitos balanços da própria existência, em que todos os aspectos importantes para o arremate da vida eram avaliados retrospectivamente. Milton Stanczyk ressaltou

\footnotetext{
${ }^{15}$ A noção da família como motor da organização social brasileira foi disseminada pela obra de Gilberto Freyre (FREYRE, 1933). Sobre o entendimento da família como base da sociedade brasileira e os caminhos da História da Família no Brasil, desde os trabalhos clássicos aos mais recentes, passando por conceitos e métodos centrais, ver: (SCOTT, 2009: 13-29).
} 
que isso incidia sobre o cerne das redes de sociabilidades e de afetos, tarefa fundamental para a escolha de pessoas com as características necessárias, do ponto de vista do testador, para uma execução bem-sucedida de suas recomendações (STANCZYK FILHO, 2005: 53). É possível sugerir algumas circunstâncias possíveis nas quais a indicação de pessoas desvinculadas do ambiente familiar teria sido preferida. Um desses cenários, aventado por Sheila de Castro Faria, dizia respeito à presença de conflitos conjugais ou disputas patrimoniais, o que estimulava o testador a nomear pessoas não diretamente interessadas na testamentaria (FARIA, 1998: 276). Uma segunda possibilidade tocava à manutenção de interesses econômicos em várias localidades e à mobilidade daí decorrente. Situações semelhantes poderiam exigir maior distribuição geográfica dos testamenteiros a partir do acionamento de uma rede mais ampla de relacionamentos que permitisse, concomitantemente, a escolha de pessoas inteiradas dos negócios (STANCZYK FILHO, 2005: 60-62).

Um terceiro fator estava relacionado à influência exercida pela Igreja, o que impulsionava a nomeação de agremiações leigas e de padres para a função. Em $26(9,66 \%)$ casos da amostra clérigos foram acionados, sem sinal de mudança ao longo do tempo, e, em apenas $3(1,12 \%)$ testamentos alguma associação leiga foi nomeada. ${ }^{16}$ Essas últimas se concentraram nas primeiras décadas do recorte, cessando de aparecer provavelmente pelo impacto da promulgação da lei de junho de 1766 que, dentre outras regulações testamentárias, proibia Ordens religiosas da execução da testamentaria (ALMEIDA, 1870: 1055-1056). Além disso, segundo Gustavo Henrique Barbosa em pesquisa sobre a Ordem Terceira de São Francisco de Mariana, a aceitação da execução da testamentaria pela instituição era assunto amplamente discutido a partir de uma visão completamente utilitarista. Consistia em condição para a aceitação do trabalho a eleição da dita Ordem como herdeira ou a destinação de esmolas suficientemente convenientes para a obtenção de recursos financeiros (BARBOSA, 2015: 152-155). O autor estimou que entre

\footnotetext{
${ }^{16}$ Percentuais muito próximos foram encontrados por Iury Matias Soares para o Rio de Janeiro da segunda metade do século XVII (SOARES, 2015).
} 
1758 e 1808 apenas $10 \%$ dos irmãos professos instituíram a Ordem como testamenteira. Destes, todos estavam enquadrados no padrão de homens solteiros e sem filhos, que, avaliou o autor, se apegavam à sociabilidade que o hábito franciscano proporcionava para resolver os assuntos póstumos. Prosseguindo a análise, ele observou que os níveis hierárquicos no interior da Ordem foram decisivos: entre os irmãos mesários, ainda que igualmente solteiros e sem filhos, sua projeção social e econômica lhes favorecia na constituição de redes de sociabilidades, lhes oferecendo situação mais vantajosa para a definição de candidatos para a execução da testamentaria, preferindo, desse modo, pessoas particulares (BARBOSA, 2015: 152).

O baixo índice de $10,78 \%$ de administração religiosa dos bens dos testadores, somando clérigos e agremiações leigas, se recobre de maior interesse quando observado que somente 10 pessoas eram nascidas nas Minas, das quais nenhuma era casada quando redigiu sua vontade, e 3 possuíam filhos vivos. Dos quase dois terços nascidos fora das Minas, outros 3 tinham filhos vivos, e somente um testador era casado, por sinal com "Josefa Marcelina da Sylva ja quinquagenaria quando com ella me despozei". ${ }^{17}$ Esse perfil apontado para os indivíduos que depositaram a tarefa da testamentaria em religiosos, em sua maioria nascidos em Portugal, marcado pela baixa presença de filhos e pela ausência de cônjuges aptos - fosse pela solteirice (18), viuvez (5), sacerdócio (5), ou pela idade avançada da esposa do único testador casado - corrobora o argumento de que as estratégias testamentárias se enquadravam numa lógica primeiramente familiar. O que se quer dizer é que se sempre houve outras estratégias disponíveis que seguiram atuantes em concorrência com as relações familiares, por outro lado, num contexto familiar mais estável, a família foi considerada em geral opção mais eficaz.

No que cabe à ordenação dos cuidados fúnebres no documento de última vontade, no avançar do século XIX, as cláusulas religiosas da documentação foram assumindo configuração distinta, marcada sobretudo pela simplificação e

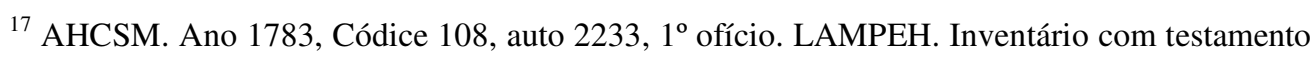
de Leonardo da Silva Campos [1780].
} 
redução. Esse processo, que atingiu em ritmos e formas diferentes todo o Ocidente cristão, foi sentido desde a escolha das mortalhas, passando pelos detalhes do sepultamento às celebrações de missas, acompanhado pelo crescimento do poder do executor. ${ }^{18}$ Longe de significar qualquer sinal de desagregação das crenças cristãs, ${ }^{19}$ o silenciamento voluntário frente às determinações decorreu da transferência das decisões para um testamenteiro de confiança (ARIÈS, 1990: 510-513; GUEDES, 1986: 51; RODRIGUES, 2005 : 313-323). De modo análogo, os pedidos de simplicidade não atingiram o essencial do cerimonial, sua liturgia, mas visavam demonstrar certo desapego dos adereços considerados supérfluos e um fortalecimento do olhar em direção à família, a colocando na posição de chancela das decisões em torno do funeral, seja na qualidade de executora ou pela elevação a primeiro plano de seus interesses.

Em Mariana, esses deslocamentos, além disso, não estiveram alheios ao enraizamento dos testadores. Ficou demonstrado como os nascidos em Portugal, solteiros em sua maioria, manifestaram preferências distintas dos nascidos na própria região (FERREIRA, 2019). A compreensão dessa mudança em curso no modelo de expressão testamentária não poderia, no caso específico dessa investigação, ser buscada sem que se levasse em conta os fatores mencionados. Fez-se premente desenhar a natureza das relações entre testadores e seus executores eleitos, categoria que, como se viu, foi progressivamente munida de maior poder e liberdade de ação, atrelada a uma maior circunscrição familiar.

Em 1796 José Francisco Alves redigiu sua vontade, emancipando seu único filho vivo, de 21 anos, Francisco Alves, o instituindo também por herdeiro e testamenteiro conjuntamente a Simplícia Maria da Paz, sua "amada molher" e herdeira de sua terça. Nenhuma outra determinação foi registrada pelo testador, que declarou que "as despoziçoens de meu enterramento bens de

\footnotetext{
18 Sobre a incidência desse movimento em cada uma das cláusulas religiosas tomadas isoladamente, ver: (FERREIRA, 2019).

19 A hipótese da "descristianização" foi difundida por Michel Vovelle da qual surgiram importantes críticas, fundamentais para os desenvolvimentos subsequentes dos estudos sobre a morte. Cf.: (VOVELLE, 1978: 325-326; DELUMEAU, 1975: 52-60).
} 
Alma, e tudo o mais deixo a eleição de meus primeiros testamenteiros nomeados aos quais pesso em tudo sigão o que muito lhes recomendo em cedulla particular que lhes deixo fechada [...]". ${ }^{20}$ Anos depois foi a vez de Ana Joaquina Soares registrar um breve testamento no qual se limitou a coartar sua escrava Maria Crioula, a nomear como herdeira Dona Eufrásia, sua filha tida antes do casamento, e a indicar seu marido, o furriel Francisco Esteves de Magalhães, como testamenteiro. Sobre seu funeral, solicitou vestes, acompanhamento e sepultura da Ordem Terceira de São Francisco da qual era agremiada, além de cinco missas de corpo presente. Por fim, declarou que "tudo aquilo que restar da minha Terça sera impregado no que deixo recomedado ao referido meu marido, e este saptisfara com hum juramento". ${ }^{21}$ Outra testadora, Ana Maria Felícia, diante da impossibilidade de nomear seus três filhos naturais por herdeiros por viveram na condição de escravizados, instituiu como tal seu marido José Lopes de Freitas e testamenteiro. A testadora lembrou que seu sepultamento seria na capela de sua irmandade de Nossa Senhora das Mercês e os demais detalhes do funeral deixou aos cuidados do marido que deveria mandar celebrar "duas Missas de corpo presente de esmolla de mil e duzentos cada huma e todos os mais suffragios que lhe passei levando-se tudo em conta". 22

Os testamentos citados, guardadas suas especificidades, ilustram o argumento que se quer demonstrar. Está-se diante de um deslocamento gradual de reconfiguração das últimas vontades sob o impulso da projeção da esfera familiar. Os assuntos post-mortem foram paulatinamente transmitidos aos mais próximos, sem que para isso fosse necessário a mobilização da esfera legal. A pesquisa desenvolvida sobre as práticas testamentárias em Orléans por Gaël Rideau é, a esse respeito, muito elucidativa. Trabalhando com uma série de documentos de 1667 a 1787, o autor observou semelhante redução do discurso

\footnotetext{
${ }^{20}$ AHCSM. Ano 1796, Códice 97, auto 2018, $1^{\text {º }}$ ofício. LAMPEH. Inventário com testamento de José Francisco Alves [1796].

${ }^{21}$ AHCSM. Ano 1825, Códice 40, auto 919, $1^{\circ}$ ofício. LAMPEH. Inventário com testamento de Ana Joaquina Soares [1824].

${ }_{22}$ AHCSM. Ano 1844, Códice 42, auto 966, $1^{\circ}$ ofício. LAMPEH. Inventário com testamento de Ana Maria Felícia [1842].
} 
religioso de um modo geral. Rideau sugere que a explicação para essa mutação devia ser buscada em uma leitura global que não se limitasse à constatação do crescente silenciamento no campo dos temas soteriológicos, mas passasse a considerar a tripla natureza do documento: religiosa, social e jurídica, e a relação dialética entre seus atores: notário, família e morto. ${ }^{23}$ A partir desses pontos orientadores, o autor observou que a transformação nas recomendações religiosas se deveu não a rejeição ou indiferença, mas à projeção da dimensão familiar, seja no campo da herança ou da execução da vontade do morto.

Da sepultura à missa, cresce o lugar do implícito que, por fim, marca a afirmação da família, tingida de direito pelas sepulturas, e de costume social pelos cortejos fúnebres. Com efeito, o executor é cada vez mais um membro da família próxima: em um caso em cada três desde 1750 e na maioria das vezes o cônjuge. Esse recurso é feito em detrimento de dois profissionais: o clérigo e o oficial. $O$ silêncio do testamento é, portanto, a expressão do deslocamento da escolha em favor de uma esfera íntima e privada, fora do campo da escrita legal. (RIDEAU, 2010: 106. Tradução nossa). ${ }^{24}$

Assim como ocorreu com a prática testamentária em Orleans, verificouse o crescimento do silêncio e do implícito entre os testadores de Mariana. Análises anteriores não permitem que se fale em abandono da preocupação salvacionista nem em modificações estruturais nas práticas fúnebres (FERREIRA, 2019). Contudo, se por um lado o repertório funerário e a

\footnotetext{
${ }^{23}$ Ver a esse respeito (BRIFFAUD, 1985: 389-409). É inegável a contribuição da proposta da análise dialética entre os sujeitos atuantes na produção das fontes testamentárias, contudo, uma relativização precisa ser feita com relação à influência exercida pelo notário nessa atividade. Briffaud apontou como a atuação notarial exerceu um peso direto sobre a composição dos testamentos e sua transformação ao longo do tempo através da seleção das fórmulas jurídicas aplicáveis e, segundo o autor, embora o impacto desses profissionais fosse mais direcionado à forma do documento e não ao seu conteúdo, é de se supor que a adoção de novos estilos, muito mais simplificados, pelos notários tenha sido acompanhada por uma redefinição equivalente do conteúdo. A atuação dos notários no Brasil, como demonstrou Aryanne Santos, teve circunscrição mais restrita à aprovação legal do documento, não exercendo influência direta no seu processo de feitura. Além disso, Cláudia Rodrigues ressaltou que é fundamental considerar ser o testador o agente principal da vontade, que usava do modelo discursivo disponível para fixar aspirações pessoais (SANTOS, 2017: 86; RODRIGUES, 2015: 17-49).

24 "De la sépulture à la messe grandit la place de l'implicite qui, à terme, marque l'affirmation de la famille, teintée de loi pour les sépultures, de coutume sociale pour les convois. En effet, l'exécuteur est de plus en plus un membre de la famille proche: dans un cas sur trois à partir de 1750 et le plus souvent le conjoint. Ce recours se fait au détriment de deux professionnels: l'ecclésiastique et l'officier. Le silence du testament est donc l'expression du déplacement du choix au profit d'une sphère intime et privée, hors du champ de l'écrit juridique."
} 
preocupação mnemônica que ele encerra como dispositivo de salvação e vida eterna não foram abandonadas nem essencialmente modificadas, por outro, o papel desempenhado pelo testamento nessa aspiração sofreu um deslocamento em direção à delegação a familiares próximos. Em relação à execução da vontade, não apenas cresceu a atuação de parentes e cônjuges, como apontado nas tabelas apresentadas, como também se verificou o alargamento das funções que escapavam ao registro formal. Desse modo, diante da presença mais incisiva das relações familiares na documentação, seu caráter religioso foi sendo simplificado na forma e no conteúdo.

Para uma compreensão mais matizada da mudança em questão, o peso a longo prazo das leis pombalinas e a força do costume são fatores que merecem escrutínio que não cabe nos limites desse artigo. ${ }^{25}$ Vale comentar que práticas amplamente difundidas de investimentos de fortunas para o bem da alma sofreram o impacto das medidas pombalinas que visavam controlar o poder econômico e político da Igreja e, no que se referia à liberdade de testar, o fez através de um discurso valorativo dos vínculos sanguíneos. Mas, assim como argumentou Alexandre Daves para o campo das práticas sucessórias, o novo posicionamento diante do direito de herança e da família parece manter na posição central o peso de uma população mais enraizada localmente, para o caso específico de Minas Gerais (DAVES, 1998: 170-181).

Jacques Chiffoleau apontou como, no fim da Idade Média, as atitudes diante da morte na região de Avinhão sofreram o impacto da mudança demográfica impulsionada pelo desenvolvimento urbano e comercial. A transformação nas sensibilidades fúnebres, movimento em andamento que a epidemia da Peste teria apenas acentuado (COHN, 2000: 21), foi marcada sobretudo pelo reforço da noção de indivíduo, através do investimento em pompas extravagantes. $\mathrm{O}$ desenraizamento afetou a relação entre mortos $\mathrm{e}$ vivos, impossibilitou a reunião familiar no post-mortem, e obrigou a criação de novas solidariedades e formas de enfrentamento da angústia da morte. $\mathrm{O}$

\footnotetext{
${ }^{25}$ Esforços nesse sentido estão sendo feitos por Claudia Rodrigues (RODRIGUES, 2015: 251285).
} 
funcionamento tradicional dos ritos e do luto foi impedido, a ideia de ruptura com a tradição e o terror da morte solitária fez crescer nos testamentos os pormenores sobre os cuidados mortuários e a teatralização dos ritos por parte dos próprios testadores. Forçados a abandonar a segurança das solidariedades familiares, "[...] desenraizados, sem antepassados, doravante os cidadãos ganham sozinhos o reino das Trevas." (CHIFFOLEAU, 1996: 128). Os ritos funerários, cuja função primeira era dar "aos mortos um lugar [...] tanto no espaço que lhes está reservado (o cemitério, a igreja) como na memória coletiva e individual dos vivos" (CHIFFOLEAU, 1996: 128), passaram a serem dedicados menos à garantia da separação entre os vivos e o defunto e mais ao reforço da individualidade desse último.

As mudanças que marcaram profundamente as sociedades da Baixa Idade Média estimularam formas distintas de comportamento em relação aos mortos e à morte, em que a estabilidade, a ruptura e a melancolia decorrente fizeram a preocupação se voltar para a própria individualidade daquele que organizava seu funeral. As perturbações causadas pelas altas taxas de mortalidade e de mobilidade impediram o funcionamento esperado dos ritos e colocaram o problema da conservação memorial. O número de testamentos cresceu sob a influência daquela conjuntura, acompanhando o aumento da “preocupação dos homens com um enterro apropriado; também a manutenção da memória tornou-se um importante objeto de regulamentação testamentária: nem o menor detalhe parece supérfluo" (OEXLE, 1996: 69). É evidente que as considerações de Chiffoleau e Oexle estavam debruçadas sobre uma conjuntura histórica singular, e não se pretende sugerir qualquer equivalência entre aquela sociedade e a que nessa pesquisa está colocada em cena. Mas, cabe ressaltar para os presentes propósitos que, assim como as crises de mortalidade, também as migrações são fenômenos capazes de exercer franca pressão sobre a relação das sociedades com os mortos e a vivência da morte.

Os deslocamentos populacionais, como colocado pelos autores citados, além de retirarem os indivíduos de sua terra de origem, os afastando geograficamente dos ancestrais, podem os desconectar de suas solidariedades 
familiar, vicinal e comunitária já estabelecidas. Essa desagregação primeira do grupo social foi capaz de abalar as expectativas soteriológicas ao incidir sobre a concepção primeira da salvação eterna, qual seja, a de que era impossível obter a salvação sozinho. As associações leigas exerceram papel de relevo nesse sentido ao serem, para seus membros adimplentes, grandes asseguradoras da dimensão ativa da coletividade no cerimonial católico de morte.

\section{O executor e a administração da memória do morto}

O horror da morte, Segundo Edgar Morin, era decorrente do sentimento ou da consciência de perda da individualidade que comanda as perturbações provocadas pela morte, o que o autor chamou de traumatismo da morte. $\mathrm{O}$ reconhecimento, ou a consciência da morte produz também sua própria contradição, isto é, a crença na imortalidade, contudo, permanece entre uma e outra aquela zona intermediária traumática, de inquietude, sustentadora de um complexo quadro de emoções e rituais fúnebres (MORIN, 1997: 34). Assim, para o autor, a crença na imortalidade nada mais era do que a afirmação da individualidade além da morte. Ao mesmo tempo, quanto maior o isolamento do indivíduo de seu grupo social, tanto maior seria seu horror da própria morte, uma vez que o pertencimento a um grupo inibe o traumatismo em seus membros, ainda que nenhuma sociedade tenha conhecido a superação absoluta de desmistificação da morte (MORIN, 1997: 37-38).

O que se quer sugerir com a mobilização desses teóricos é que o desenraizamento inicial, não apenas geográfico, mas de laços de parentesco e da comunidade, que a vinda para as Minas provocou em parte dos testadores, parece ter exercido grande impacto sobre o uso que correntemente se fez do testamento como documento de ordenação minuciosa do funeral. Como ideal a ser alcançado, a salvação esteve atrelada ao envolvimento da coletividade, e o testamento, por sua vez, terminava por organizar uma socialização da morte na qual o testador projetava sua morte diante do corpo social. Lançando mão dos 
rituais fúnebres públicos, o indivíduo se esforçava para ser conservado na memória coletiva e desfrutar da intercessão dos vivos.

Já se apontou e continua sendo importante destacar como uma faceta fundamental da constituição da sociedade marianense a atuação das redes de acolhimento e sociabilidades tais como irmandades, relações de vizinhança e vínculos profissionais. Laços semelhantes a esses, correntemente denominados pela teoria social de "fracos" por apresentarem maior dispersão, mas uma oferta igualmente maior de contatos, foram essenciais para a formação social e em grande medida responsáveis pela inserção dos imigrantes nas teias sociais (GRANOVETTER, 1973: 1360-1380; ALFANI, 2012: 47-73). Quando institucionalizados na figura das agremiações leigas, serviram ao assistencialismo na vida e na morte. Entretanto, no exercício de preparação para a morte, essas relações, efetivas, mas diluídas, não forneciam o arcabouço necessário para inibir nos testadores a inquietação diante da ideia da própria morte, no máximo, aí no caso das associações religiosas, garantiam os serviços funerários básicos mediante o acerto dos anuais.

Sem anular, desse modo, a força dos laços fracos e sua reconhecida função social, o que se observou nas fontes consultadas foi que os laços baseados no parentesco ou no casamento ofereciam maior conforto a seus membros nos últimos momentos. Essa disposição para com o núcleo familiar pode ser compreendida quando se considera a saliente dimensão mnemônica na qual estava submetida a ideia da boa morte. $\mathrm{O}$ entendimento do funcionamento e da duração dessa memória que alicerçava as trocas mútuas entre vivos e os mortos passa pela especulação sobre a intensidade dos vínculos sociais. Segundo Roberto DaMatta:

Num sentido estritamente empírico, pode-se dizer que a nossa noção de "alma" corresponde muito de perto a uma memória viva do morto, que vai ficando mais tênue à medida que o tempo entre esse morto e sua comunidade passa. Mas isso não seria dizer tudo. Porque a memória do morto é certamente uma noção relacional, a memória sendo um conceito que traduz o modo e a intensidade de uma relação social. [...] Quanto mais saudade, mais intensa é a memória do morto ou do lugar. Quanto menos saudade, menos intensidade na recordação. (DAMATTA, 1997: 155). 
O trecho citado sintetiza algumas considerações basilares sobre as relações entre morte, recordação e sociabilidades. Sendo a lembrança o exercício indispensável à manutenção das relações entre os dois planos (terrestre e celeste) fundamentais da existência (DAMATTA, 1997: 155), ela está necessariamente submetida à capacidade do ser que recorda. E, embora a faculdade de memória não deixe de ser um fenômeno psíquico, portanto individual, como advogou a tradição filosófica fenomenológica (RICOEUR, 2007: 107-129), ela se desenrola com materiais fornecidos pelo meio social, não deixando de ser sempre, em alguma medida, memória coletiva (HALBWACHS, 2005: 25-52). A depender da circunstância em questão, o individual ou o coletivo adquirem projeção, mantendo, contudo, certo grau de entrelaçamento. Mas, entre esses dois polos, Paul Ricoeur identificou um plano intermediário: a memória dos próximos. Os próximos estão na faixa de variação entre o si, o foro interior e as sociabilidades mais alargadas, o espaço público. A condição privilegiada presente na relação com os próximos se deve a essa variação de distância que os coloca como outros mais próximos do nós, por isso a eles é atribuída uma memória e expectativas distintas. Os próximos são, em outros termos, aqueles que "[...] acrescentam uma nota especial referente aos dois 'acontecimentos' que limitam uma vida humana, o nascimento e a morte. [...] ambos importaram ou vão importar para os meus próximos" (RICOEUR, 2007: 141).

Contendo a memória, desse modo, uma dimensão catalisadora pautada no afeto, vínculos mais estreitos asseguravam uma sobrevivência memorial (ainda que se possa argumentar que de extensão limitada a uma ou duas gerações) que as instituições religiosas e os testamentos garantiam somente até o limite de duração das missas previstas nos compromissos das irmandades ou encomendadas pelo próprio morto. O que está em questão é então a função mnemônica do testamento empregada com fins salvacionistas frente à presença ativa da família, grupo portador de predicados que estimulavam uma sobrevivência memorial mais duradoura para seus membros falecidos. 
A memória de natureza litúrgica ${ }^{26}$ não foi aqui eclipsada, visto que sua função salvífica, ao intencionar que os vivos, intercessores pelas almas falecidas, se lembrassem de seus mortos, foi conservada, embora cada vez mais sob o jugo do engajamento familiar. Essa mudança na expressão testamentária que contém em si os limites, uma vez que a dimensão salvacionista é mantida, marcava um deslocamento na valorização da experiência familiar. A preocupação salvacionista que o testamento mantinha enquanto meio de recordação, no Oitocentos foi cedendo espaço a outra disposição, também de natureza mnemônica, que sempre a acompanhou, mas anteriormente submetida a ela: o desejo de se fazer lembrado pelos entes queridos e membros da família. Esse modo de memória, por falta de termo mais adequado, pode ser chamado de intransitivo (TODOROV, 2000), na medida em que a sobrevivência pela memória, nesse caso pela memória dos próximos, é assumida quase como um objetivo "em si mesmo". É claro, contudo, que essa afirmação não pode ser levada às suas últimas consequências, uma vez que a memória nesse caso também se prestava a algo, como ao reforço da coesão de um grupo ao servir de alimento para construções identitárias e de pertencimento (LE WITA, 1984: 57 66; LE WITA, 1985: 15-26). O que se quer salientar é que as cláusulas testamentárias acentuaram a memória como uma espécie de canal imortalizador. Este foi se mantendo em coexistência com a crença na ideia de salvação, não a suplantando, mas assumindo importância crescente no enfrentamento do drama da morte. Essa eternização da/pela memória do testador passava a depender da capacidade dos membros familiares de perpetuála. Os cuidados necessários para com o testador começavam a ser, sobretudo, ritos familiares.

Os meios de memória disponíveis no universo familiar, por seu turno, prescindiam de atos escritos. O capital cultural familiar, como demonstrou Louis Assier-Andrieu ao se debruçar sobre os dispositivos memoriais de gerações de uma mesma família, se sustenta por outros materiais - mais

\footnotetext{
${ }^{26}$ Modalidade de recordação a qual, pelos usos que dela eram feitos, pode-se atribuir o adjetivo de litúrgica dada a estreita relação mantida entre memória e intercessão pelo ser recordado, tendo como motor pretensões de natureza salvífica (OEXLE, 1996: 35).
} 
remetidos à oralidade e à informalidade - de modo que os registros notariais são apenas consequências dessa perpetuação, não condição de sua existência. Embora sejam fontes essenciais para o ofício do historiador, os atos notariais, para aqueles a quem eles diziam respeito diretamente, eram mais simbólicos do que informativos e poderiam fornecer certas garantias e apoio para a vida doméstica, mas não era por meio eles que as memórias seriam preservadas (ASSIER-ANDRIEU, 1997: 10-33). Desse modo, em um universo favorecedor da vivência familiar, outros meios de memória disponíveis, predominantemente orais e transmitidos pelos mais próximos, atuavam com maior eficácia, tornando os atos notariais dispensáveis e débeis enquanto meios de recordação em seu sentido amplo.

A atenção foi direcionada, portanto, à transmissão para o âmbito familiar de decisões e cuidados antes remetidos à esfera pessoal, se valendo do recurso à prática testamentária e das associações leigas. O avançar do enraizamento populacional na região mineradora manifestado nas fontes por testadores mais remetidos aos vínculos familiares, acredita-se, desempenhou papel central no deslocamento verificado na formulação das últimas vontades, onde se passou de testamentos com conteúdo religioso mais detalhado para documentos que delegavam parte considerável dessas decisões a outrem.

O que está em questão, como tentou-se demonstrar, é, como ao longo do recorte cronológico, a esfera familiar invadiu a dimensão religiosa, constituindo maneiras alternativas de expressão e preparação para a morte. A mudança testamentária não parece ter implicado em transformações equivalentes nas práticas e concepções religiosas como efetivamente praticadas pela sociedade, mas atuou no sentido de um gradual encaixe em uma lógica familiar. Embora não se trate de uma ruptura, há um inegável deslocamento, marcado pela reconfiguração do discurso e seu direcionamento para uma estratégia doméstica, parental. 


\section{Referências}

AHCSM. Cartório do $1^{\circ}$ Ofício. Livros de registro de testamento. 1748-1848. Livros números: 5, 17, 26, 31, 32, 45, 54, 55, 59, 70, 74.

ALFANI, G. Immigrants and formalisation of social ties in Early Modern Italy: Ivrea in the sixteenth and seventeenth centuries. In: ALFANI, G.; GOURDON, V. (eds.). Spiritual kinship in Europe, 1500-1900. London: Palgrave Macmillan, 2012.

ALMEIDA, C. M. de. Código Philippino ou Ordenações e Leis do reino de Portugal: recopiladas por mandado d'El-Rey D. Philippe I. Rio de Janeiro: Typ. do Instituto Philomathico, 1870.

ANTUNES, A. de A. A forma de fazer testamento: apontamentos acerca de um opúsculo setecentista. Revista Eletrônica de História do Brasil, v. 7, n. 2, p. 93101, jul.-dez., 2005.

ARAÚJO, A. C. A Morte em Lisboa: atitudes e representações (1700-1830). Lisboa: Notícias editorial, 1997.

ARIÈS, P. História da morte no Ocidente: da Idade Média aos nossos dias. Trad. Priscila Viana de Siqueira. Rio de Janeiro: Nova Fronteira, 2012.

ARIÈS, P. O amor no casamento. In: ARIÈS, P. e BÉJIN, A. (Orgs.). Sexualidades Ocidentais: contribuição para a história e a sociologia da sexualidade. Trad. Lygia Araújo Watanabe e Thereza Christina Ferreira Stummer. São Paulo: brasiliense, 1985.

ARIÈS, P. O Homem diante da morte. Trad. Luiza Ribeiro. Rio de Janeiro: Francisco Alves, 1990.

ASSIER-ANDRIEU, L. Maison de mémoire. Structure symbolique du temps familial en Languedoc: Cucurnis. Terrain - Anthropologie \& sciences humaines, Paris, n. 9, p. 10-33, out 1997.

BARBOSA, G. H. Poderes locais, devoção e hierarquias sociais: a Ordem Terceira de São Francisco de Mariana no século XVIII. 2015. 369 f. Tese (Doutorado em História) - Faculdade de Filosofia e Ciências Humanas, Universidade Federal de Minas Gerais, Belo Horizonte, 2015.

BOSCHI, C. C. Os Leigos e o Poder: Irmandades leigas e política colonizadora em Minas Gerais. São Paulo: Ática, 1986.

BOTELHO, T. R. A família mineira no século XIX. In: RESENDE, M. E. L. de; VILlaltA, L. C. (orgs.). A Província de Minas, 2. Belo Horizonte: Autêntica editora; Companhia do Tempo, 2013. 
BRIFFAUD, S. La famille, le notaire et le mourant: testament et mentalités dans la région de Luchon (1650-1790). Annales du Midi: revue archéologique, historique et philologique de la France méridionale, Toulouse, v. 97, n. 172, p. 389-409, 1985.

BRÜGGER, S. M. J. Compadrio e patriarcalismo: relações familiares e de poder (São João del-Rei, 1780-1850). In: RESENDE, M. E. L. de; VILLALTA, L. C. (orgs.). História de Minas Gerais: a Província de Minas, 2. Belo Horizonte: Autêntica; Companhia do Tempo, 2013.

CASTRO, E. de. Breve aparelho e modo fácil para ajudar a bem morrer um cristão, com a recopilação da matéria de tratamentos, e penitência, várias orações devotas, tiradas da Escritura Sagrada, e do Ritual Romano de N. S. P. Paulo V, acrescentada da devoção de várias missas. Lisboa: por Mattheus Pinheiro: a custa de Adrião de Abreu, 1627.

CHARTIER, R. Les Arts de Mourir, 1450-1600. Annales. Histoire, Sciences Sociales, Paris, v. 31, n. 1, p. 51-75, 1976.

CHIFFOLEAU, J. O que faz a morte mudar na região de Avinhão no fim da Idade Média. In: BRAET, H.; VERBEKE, W. (eds.). A morte na Idade Média. Trad. Heitor Megale, Yara Frateschi Vieira, Maria Clara Cescato. São Paulo: edusp, 1996.

COHN Jr., S. K. The place of the dead ins Flanders and Tuscany: towards a comparative history of the Black Death. In: GORDON, B.; MARSHALL, P. (eds.). The place of the dead: death and remembrance in late medieval and early modern Europe. Cambridge: Cambridge University Press, 2000.

COSTA, A. P. P. Atuação de poderes locais no império lusitano: uma análise de perfil das chefias militares dos Corpos de Ordenança e de suas estratégias na construção de sua autoridade - Vila Rica (1735-1777). 2006. 150 f. Dissertação (Mestrado em História) - Instituto de Filosofia e Ciências Sociais, Universidade Federal do Rio de Janeiro, Rio de Janeiro, 2006.

DAMATTA, R. A casa \& a rua: espaço, cidadania, mulher e morte no Brasil. 5. ed. Rio de Janeiro: Rocco, 1997.

DAVES, A. P. Vaidade das Vaidades: os homens, a morte e a religião nos testamentos da comarca do Rio das Velhas (1716-1755). 1998. 310 f. Dissertação (Mestrado em História) - Faculdade de Filosofia e Ciências Humanas, Universidade Federal de Minas Gerais, Belo Horizonte, 1998.

DA VIDE, S. M. Constituições Primeiras do Arcebispado da Bahia. Feitas, e ordenadas pelo ilustríssimo, e reverendíssimo senhor D. Sebastião Monteiro da Vide: Propostas e Aceitas em o Synodo Diocesano, que o dito Senhor celebrou 
em 12 de junho do anno de 1707. Typografia de Antônio Louzada Antunes, São Paulo: 1853.

DELUMEAU, J. Au sujet de la déchristianisation. Revue d'Histoire Moderne \& Contemporaine. Paris, tomo 22, n. 1, p. 52-60, jan-mar 1975.

DOSSE, F. História e Ciências Sociais. Trad. Fernanda Abreu. Bauru: Edusc, 2004. pp. 183-184.

FAMILYSEARCH. Registros paroquiais de óbitos da Paróquia de Nossa Senhora da Assunção, Catedral de Mariana. Livros referentes aos anos: 17641776, 1777-1786, 1783-1805, 1721- 1789, 1840-1848, 1750-1768, 1756-1815, 1777-1797, 1780-1802, 1801-1837, 1803-1813, 1826-1839.

FARIA, S. de C. A Colonia em movimento. Rio de Janeiro: Nova Fronteira, 1998.

FERREIRA, K. A. de L. A Boa Morte em Mariana: sociabilidade e memória nas expressões e nos atores testamentários (1748-1848). 2016. 70 f. Monografia (Bacharelado em História) - Departamento de História, Universidade Federal de Viçosa, Viçosa, 2016.

FERREIRA, K. A. de L. Morte, memória e família: a prática e os atores testamentários em Mariana, 1748-1848. 2019. 135 f. Dissertação (Mestrado em História) - Faculdade de Filosofia e Ciências Humanas, Universidade Federal de Minas Gerais, Belo Horizonte, 2019.

FREYRE, G. Casa-grande e senzala: formação da familia brasileira sob o regimen de economia patriarchal. Rio de Janeiro: Maia \& Schmidt Ltda: 1933.

GRANOVETTER, M. S. The strength of weak ties. American Journal of Sociology, Chicago, v. 78, n. 6, p. 1360-1380, 1973.

GUEDES, S. P. L. de C. Atitudes perante a morte em São Paulo (séculos XVII a XIX). 1986. 153 f. Dissertação (Mestrado em História). Faculdade de Filosofia, Letras e Ciências Humanas, Universidade de São Paulo, São Paulo, 1986.

HALBWACHS, M. A memória coletiva. São Paulo: Editora Centauro, 2005.

LAMPEH, AHCSM. Cartório do $1^{\circ}$ Ofício. Testamentos anexados aos inventários post-mortem. 1748-1848.

LE WITA, B. Mémoire: l'avenir du présent. Terrain - Anthropologie \& sciences humaines, Paris, n. 4, p. 15-26, mar 1985. 
LE WITA, B. La mémoire familiale des Parisiens appartenant aux classes moyennes. Ethnologie française, Paris, tomo 14, n. 1, p. 57-66, jan-mar 1984.

LEMOS, G. Aguardenteiros do Piranga: família, produção de riqueza e dinâmica do espaço em zona de fronteira agrícola, Minas Gerais, 1800-1856. 2012. 170 f. Dissertação (Mestrado em História) - Faculdade de Filosofia e Ciências Humanas, Universidade Federal de Minas Gerais, Belo Horizonte, 2012.

LEWIN, L. Surprise Heirs: Illegitimacy, Patrimonial Rights, and Legal Nationalism in Luso-Brazilian Inheritance, 1750-1821. Vol. 1. Stanford: Stanford University Press, 2003.

LIBBY, D. C.; FRANK, Z. L. Uma família da Vila de São José: empregando a reconstituição familiar pormenorizada para elucidar a História Social. In: LIBBY, D. C. et al. História da Família no Brasil (séculos XVIII, XIX e XX): novas análises e perspectivas. 1. ed. Belo Horizonte: Fino Traço, 2015. p. 5195.

LOPES, L. F. R. Vigilância, distinção \& honra: os familiares do Santo Ofício na Freguesia de Nossa Senhora da Conceição de Guarapiranga - Minas Gerais (1753-1801). 2012. 170 f. Dissertação (Mestrado em História) - Instituto de Ciências Humanas, Universidade Federal de Juiz de Fora, Juiz de Fora, 2012.

MENDES, F. F. Recrutamento militar e construção do estado no Brasil imperial. Belo Horizonte: Argvmentvm, 2010.

MORIN, E. O homem e a morte. Trad. Cleone Rodrigues. Rio de Janeiro: Imago, 1997.

NASCIMENTO, M. R. do. Irmandades Leigas em Porto Alegre: práticas funerárias e experiência urbana (séculos XVIII-XIX). 2006. 362 f. Tese (Doutorado em História) - Instituto de Filosofia e Ciências Humanas, Universidade Federal do Rio Grande do Sul, Porto Alegre, 2006.

OEXLE, O. G. A presença dos mortos. In: BRAET, H.; VERBEKE, W. (eds.). A morte na Idade Média. Trad. Heitor Megale, Yara Frateschi Vieira, Maria Clara Cescato. São Paulo: edusp, 1996.

REIS, J. J. A Morte é uma Festa: Ritos fúnebres e revolta popular no Brasil do século XIX. São Paulo: Companhia das Letras. 1991.

RICOEUR, P. A memória, a história, o esquecimento. Trad. Alain François [et al.]. Campinas: editora da UNICAMP, 2007.

RIDEAU, G. Pratiques testamentaires à Orléans, 1667-1787. Revue d'Histoire Moderne \& Contemporaine. Paris, v. 4, n. 57, p. 97-123, 2010. 
RODRIGUES, C. Estratégias para a eternidade num contexto de mudanças terrenas: os testadores do Rio de Janeiro e os pedidos de sufrágios no século XVIII. Locus - Revista de História, Juiz de Fora, v. 21, n. 2, p. 251-285, jul./dez. 2015.

RODRIGUES, C. Nas Fronteiras do Além: a secularização da morte no Rio de Janeiro (séculos XVIII e XIX). Rio de Janeiro: Arquivo Nacional, 2005.

RODRIGUES, C. O uso de testamentos nas pesquisas sobre atitudes diante da morte em sociedades católicas de Antigo Regime. In: GUEDES, R.;

RODRIGUES, C.; WANDERLEY, M. da R. (Orgs.). Últimas Vontades: testamento, sociedade e cultura na América ibérica. Rio de Janeiro: Mauad X, 2015 .

SANTOS, A. F. F. dos. O fazer testamentário no teatro do bem morrer católico no Rio de Janeiro setecentista. 2017. 213 f. Dissertação (Mestrado em História) - Departamento de História, Universidade Federal do Estado do Rio de Janeiro, Rio de Janeiro, 2017.

SCARANO, J. Devoção e Escravidão: a Irmandade de Nossa Senhora do Rosário dos Pretos no Distrito Diamantino no Século XVIII. $2^{\mathrm{a}}$ ed. São Paulo: Ed. Nacional. 1978.

SCOTT, A. S. V. As teias que a família tece: uma reflexão sobre o percurso da história da família no Brasil. História: Questões e Debates, Curitiba, v. 51, n. 2, p. 13-29, jul/dez. 2009.

SCOTT, A. S. V. Famílias, Formas de União e Reprodução Social no Noroeste Português (Séculos XVIII e XIX). NEPS - Universidade do Minho, Guimarães, 1999.

SILVA, M. B. N. da. Ser nobre na colônia. São Paulo: Editora Unesp, 2005.

SOARES, I. M. Os agentes vivos do bem morrer: o testamenteiro e o juízo eclesiástico nas execuções testamentárias do Rio de Janeiro colonial. 2015. 85 f. Monografia (Graduação em História) - Departamento de História, Universidade Federal do Estado do Rio de Janeiro, Rio de Janeiro, 2015.

STANCZYK FILHO, M. À luz do cabedal: acumular e transmitir bens nos sertões de Curitiba (1695-1805). 2005. 137 f. Dissertação (Mestrado em História) - Setor de Ciências Humanas Letras e Artes, Universidade Federal do Paraná, Curitiba, 2005.

TODOROV, T. Los abusos de la memoria. Barcelona: Paidós, 2000. 
PRÁTICAS TESTAMENTÁRIAS EM MARIANA: OS EXECUTORES DAS ÚLTIMAS VONTADES NOS SÉCULOS XVIII E XIX

VOVELLE, M. Piété baroque et déchristianisation en Provence au XVIIIe siècle. Paris: Seuil, 1978

Recebido em: 12 de novembro de 2019 Aceito em: 27 de março de 2020 